\title{
Will South Asia Achieve the Sustainable Development Goals by 2030 ? Learning from the MDGs Experience
}

\author{
M. Niaz Asadullah ${ }^{1} \cdot$ Antonio Savoia $^{2}$ (D Kunal Sen ${ }^{3}$
}

Accepted: 27 June 2020 / Published online: 4 July 2020

(c) The Author(s) 2020

\begin{abstract}
This paper contributes to the debate on the Sustainable Development Goals progress by evaluating the MDGs achievements in South Asia and the policy and institutional challenges deriving from such experience. Using cross-country regressions and aggregate indicators of poverty, health, education and gender parity outcomes, we offer three sets of findings. First, comparative evidence shows that, while South Asia has converged with richer regions, there is still significant variation in gender equality, universal primary education, and income poverty achievements across countries. Second, projections based on past trends on where SDGs are expected to be by 2030 reveal that there is a long way to go, where emblematic targets as income poverty eradication may not be met in the populous South Asian countries. Finally, considering the expanded set of development targets in the SDGs and the growth slowdown in South Asia, we argue that further progress would simultaneously require increased public spending on health and education and reforms improving state capacity. A simulation exercise confirms that such a combination of interventions would deliver significant benefits in the region, particularly in areas that are critical to progress on the goals of 'No Poverty', 'Quality Education', 'Gender Equality', and 'Inclusive Growth'.
\end{abstract}

Keywords South Asia · Poverty indicators · Development indicators · Public expenditure · State capacity $\cdot$ Quality of governance $\cdot$ Sustainable development goals $\cdot$ Millennium development goals

JEL Classification D73 · O17

Antonio Savoia

antonio.savoia@manchester.ac.uk

M. Niaz Asadullah

m.niaz@um.edu.my

Kunal Sen

sen@wider.unu.edu

1 Department of Economics, Faculty of Economics and Administration, University of Malaya, 50603 Kuala Lumpur, Malaysia

2 Global Development Institute, The University of Manchester, Arthur Lewis Building, Oxford Road, Manchester M13 9PL, UK

3 UNU-WIDER, Katajanokanlaituri 6 B, 00160 Helsinki, Finland 


\section{Introduction}

South Asian countries have in large part significantly improved their human development status in the last two decades. Bangladesh, Nepal and Sri Lanka have met most of the Millennium Development Goal (MDGs) targets in the areas of poverty alleviation, food security, primary school enrolment, gender parity in primary and secondary level education, infant and under-five mortality ratio and immunisation coverage (Mahmud et al. 2013; Asadullah et al. 2014; United Nations 2015). At the same time, populous countries in South Asia such as India and Pakistan have not able to achieve MDG targets in Goal 1 on eradicating extreme poverty and hunger, Goal 4 on reducing child mortality and Goal 5 on improving maternal health. ${ }^{1}$ Perhaps reflecting this mixed record in human development outcomes, countries in the region have the second lowest Human Development Index in the world and the majority of world's population suffering from multi-dimensional poverty (Alkire and Robles 2016). The region accounts for nearly two-fifths of the world's income poor, for nearly half of the world's malnourished children, has the largest number of stunted children in the world and suffers from a number of infrastructure gaps (United Nations 2016; UNESCAP 2017).

As the MDGs period has just ended, evaluating South Asia's achievements is the next necessary step to identify and inform the set of policy priorities for the Sustainable Development Goals (SDGs). The global adoption of SDGs per se, as in the case of the MDGs adoption (see Fukuda-Parr and Hulme 2011), is likely to mobilise political consensus and policy focus on the broad agenda of international development. This should accelerate future progress. But under which conditions can it succeed? The effectiveness of this renewed global development effort will depend on the underlying structural conditions at national level, resulting also from the legacy of the MDGs pursuit. This is particularly so because the SDGs agenda is more ambitious, adopting a greater set of targets, and more resource-intensive than the MDGs. It involves a wider set of inputs, which implies greater pressure on national governments to mobilise resources and to improve policy design and delivery. ${ }^{2}$ The recent debate has indeed considered the possibility that SDGs progress may depend on countries' initial conditions (Page and Pande 2018; Asadullah and Savoia 2018). However, this is an aspect that awaits systematic investigation and so motivates this study. ${ }^{3}$

This paper contributes to the debate on human development progress (Ranis and Stewart 2012), as well as to the nascent literature assessing the SDGs prospects (Weststrate et al. 2019), by evaluating the policy and institutional challenges for South Asia. And we do so by trying to learn lessons from the legacy of the MDGs pursuit. Such an assessment,

\footnotetext{
1 See recent United Nations Development Programme (UNDP) evidence and discussion for India (at https ://www.in.undp.org/content/india/en/home/post-2015/mdgoverview.html) and Pakistan (at https://www. undp.org/content/dam/pakistan/docs/MDGs/MDG2013Report/UNDP-Report13.pdf for Pakistan).

2 The recent policy debate and SDG Goal 17 itself refer to strengthening the so-called "Means of Implementation". See Jones (2017) and Elder et al. (2016) on how they have evolved with respect to the MDGs period and the implications for development cooperation within the "Leaving No One Behind" agenda.

3 Page and Pande (2018) have argued that a key requirement to end income poverty by 2030 are that states improve their ability to reach and to be accountable to the poor, because economic growth and aid alone may not be enough. Regarding the specific MDG goal of poverty eradication, Asadullah and Savoia (2018) proposed a similar argument and offered econometric evidence that greater state capacity has been a key governance requirement to accelerate reduction in income poverty during the MDGs period. Earlier evidence on a broader set of MDGs targets, also suggests that starting positions in terms of institutional quality (and excessive economic inequality) strongly conditioned future progress (Lo Bue and Klasen 2013).
} 
linking MDGs achievements to SDGs prospects, is missing and it is our main task. ${ }^{4}$ Methodologically, the paper relies on regression-based evidence and aggregate indicators of poverty, health, education and gender parity at country level. It also offers comparative evidence and short country studies, exploring the characteristics of most and least successful cases of MDGs progress in the region. Looking at 'extreme' cases (rather than the whole distribution, capturing average effects), it is insightful in a complementary way in order to identify any systematic policy patterns related to progress or stagnation.

The analysis has three steps. First, we provide comparative evidence on MDGs progress. The MDGs period saw steady improvement in social indicators, showing evidence of convergence of South Asia with richer regions in gender equality, primary school enrolment, and income poverty, but there is still significant variation in such achievements across the region. Country-specific innovative solutions may explain cases of exceptional MDGs progress, together with the state's ability to supply public goods and services. Second, we present new regression-based evidence assessing where progress for selected SDGs outcomes - on income poverty, child mortality and gender parity-is expected to be by 2030. Despite its significant progress during the MDGs period, our projections indicate that there is a long way to go, where emblematic targets, such as income poverty eradication, may not be met by 2030 .

Finally, we analyse what could accelerate SDGs progress. Given the expanded set of development targets included in the SDGs and considering the growth slowdown in South Asia, we argue that the challenge of further progress would simultaneously require greater social spending and governance reforms aimed at improving state capacity. We illustrate this with new evidence from a simple simulation exercise, showing that a combination of improvements in state capacity and increase in health and education expenditure will deliver significant benefits in the region. This is particularly the case in areas that are critical to the region's progress on the goals of No Poverty (SDG1), Quality Education (SDG4), Gender Equality (SDG5), and Inclusive Growth (SDG8). In fact, after the MDGs era, South Asia's initial conditions see the region lagging behind in many relevant aspects, such as disadvantages in educational outcomes, proportion of girls marrying young, violence against women, multi-dimensional poverty, and economic inequality.

The rest of the paper is organised as follows. Section 2 revisits achievements in selected MDGs areas in South Asia, presenting comparative and case study evidence. Section 3 assesses where progress in selected areas will be by 2030. Section 4 discusses SDGs governance and resource challenges facing the region in the context of SDGs 1, 4, 5 and 8. Section 5 concludes, discussing development strategies and the policy priorities.

\subsection{A South Asia's MDGs Surprise?}

How has South Asia fared in terms of MDGs progress? Could this have reflected simply its initial conditions, such as income level? In this section, we first look at its performance compared to other regions over recent history, from the 1990s to the end of the MDGs period. Then we discuss the performance of individual countries, to ascertain if there are any systematic patterns explaining the variation in MDGs progress within the region.

\footnotetext{
4 The recent literature on South Asia development has looked at specific development goals progress in individual countries, as we will show through the paper, or has looked at the development trajectory of the region in historical perspective (Osmani 2018 is an excellent example). But no study has hitherto systematically assessed the SDGs prospects and how the MDGs record can affect future progress.
} 

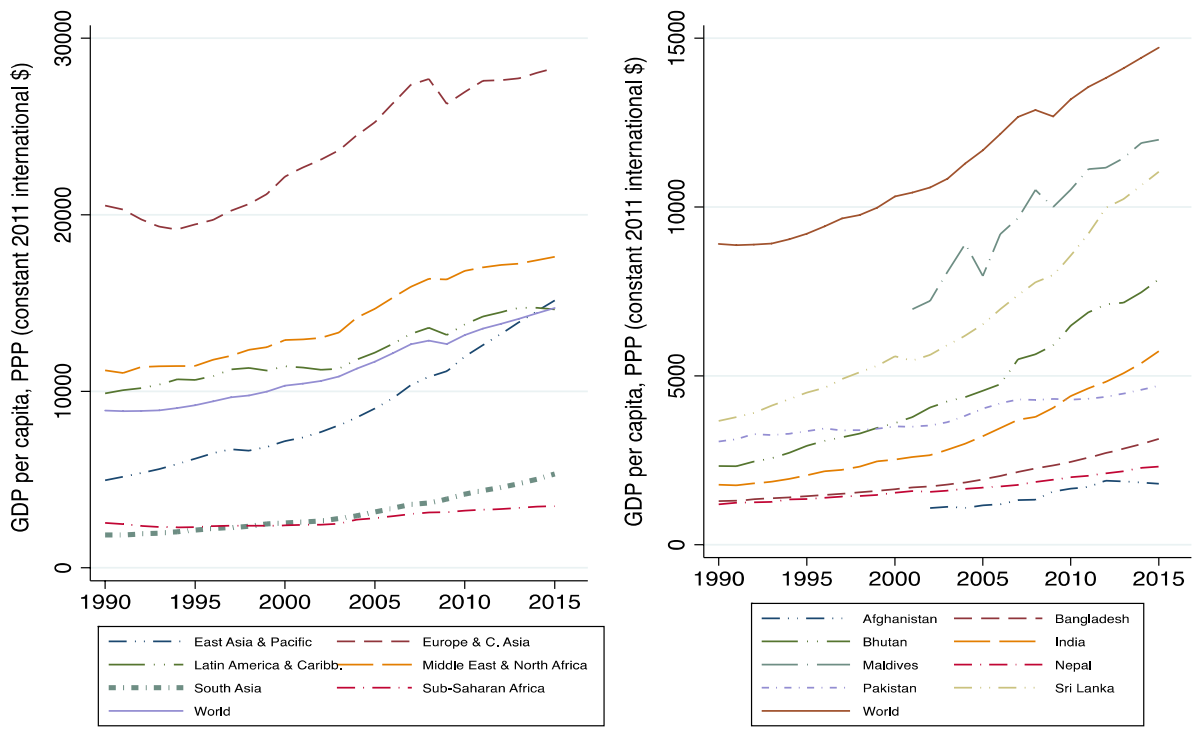

Fig. 1 GDP per capita, PPP (constant 2011 international \$). Source: World Bank (2017)

\subsection{South Asia's MDGs Achievements in Comparative Perspective}

South Asia seems to have benefitted from a period of prolonged growth, which has nearly tripled its per capita GDP over 1990-2015, following a similar trajectory to SubSaharan Africa (Fig. 1). In comparative terms, however, it seems a lacklustre performance: with increasing per capita income, but failing to catch up with and even diverging from the rest of the world. The South Asian region's per capita income remains low by international standards. Compare this with the subsequent evolution of social indicators and we often find a surprising performance for South Asia.

Starting with poverty eradication (MDG Goal 1), we generally see that South Asia significantly reduced poverty headcount and gap (Fig. 2), showing evidence of convergence to other higher income regions. Significant are also the reduction of undernourishment across the population (Fig. 2), but the region remains a laggard with respect to this dimension. Regarding Goal 4, South Asia has markedly reduced child mortality over the 1990-2015 period (Fig. 3), more than halving under-5 and infant mortality rates and so catching up with higher income regions. These achievements may have come also as a result of a spectacular increase in immunization.

MDG Goal 2, on achieving universal primary education, has seen important progress on primary school enrolment (Fig. 4). However, the same cannot be said of other dimensions of education: the region still remains largely behind in terms of literacy rates, despite seeing improvements both for male and females. Finally, on promoting gender equality (MDG Goal 3), South Asia has seen a very steep upward trajectory in the ratio of female to male enrolled in the school system (Fig. 5), even gaining the lead at 

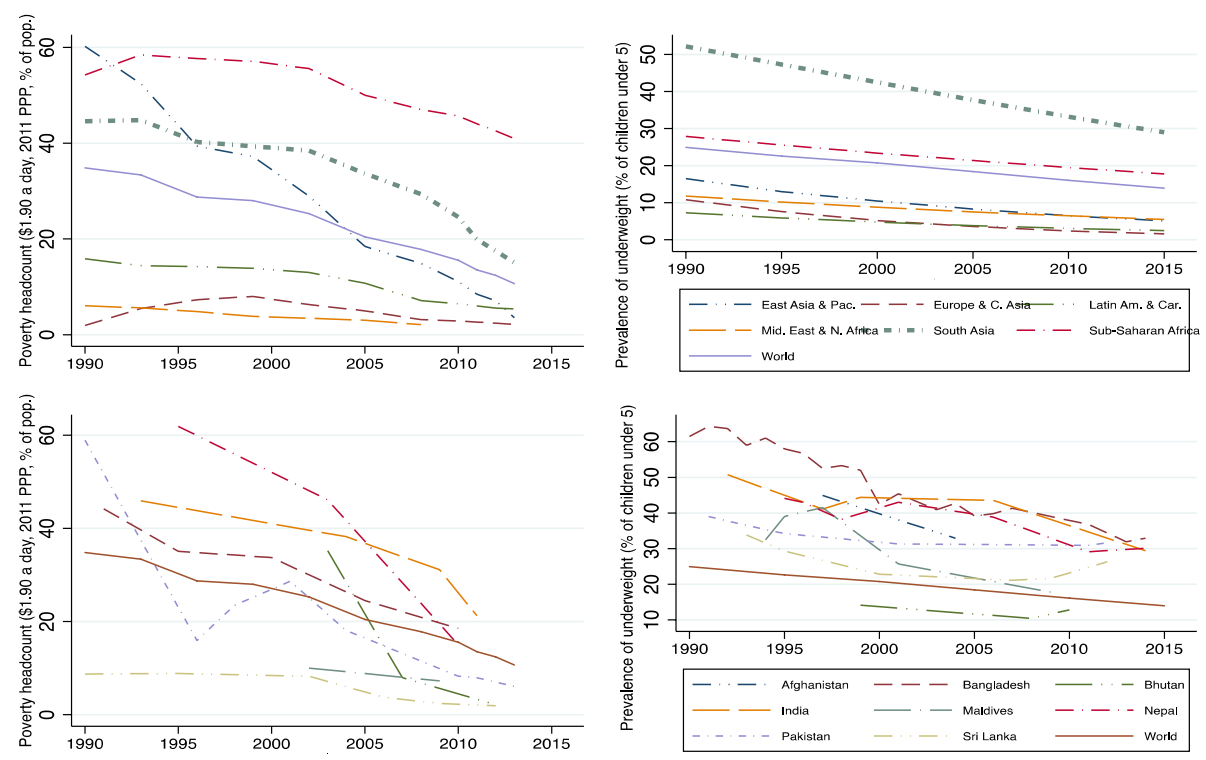

Fig. 2 Poverty eradication (MDG Goal 1): selected indicators. Source: World Bank (2017)
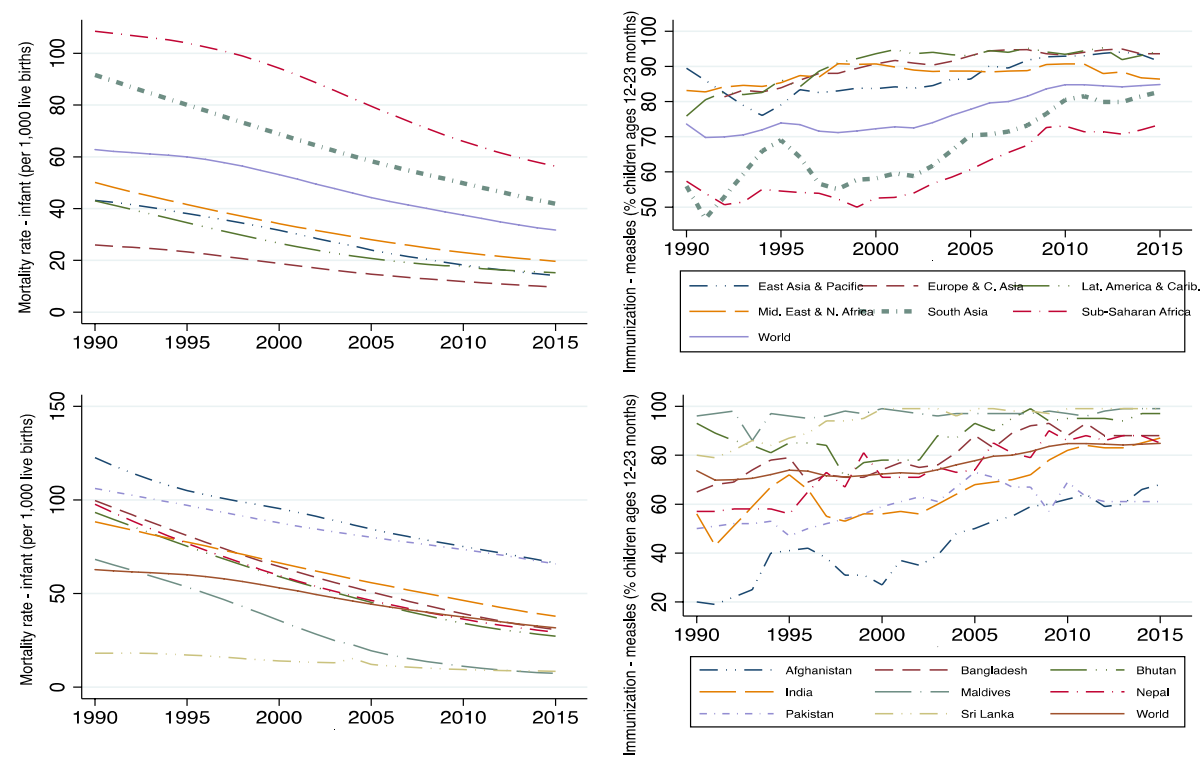

Fig. 3 Reduce child mortality (MDG Goal 4): selected indicators. Source: World Bank (2017) 

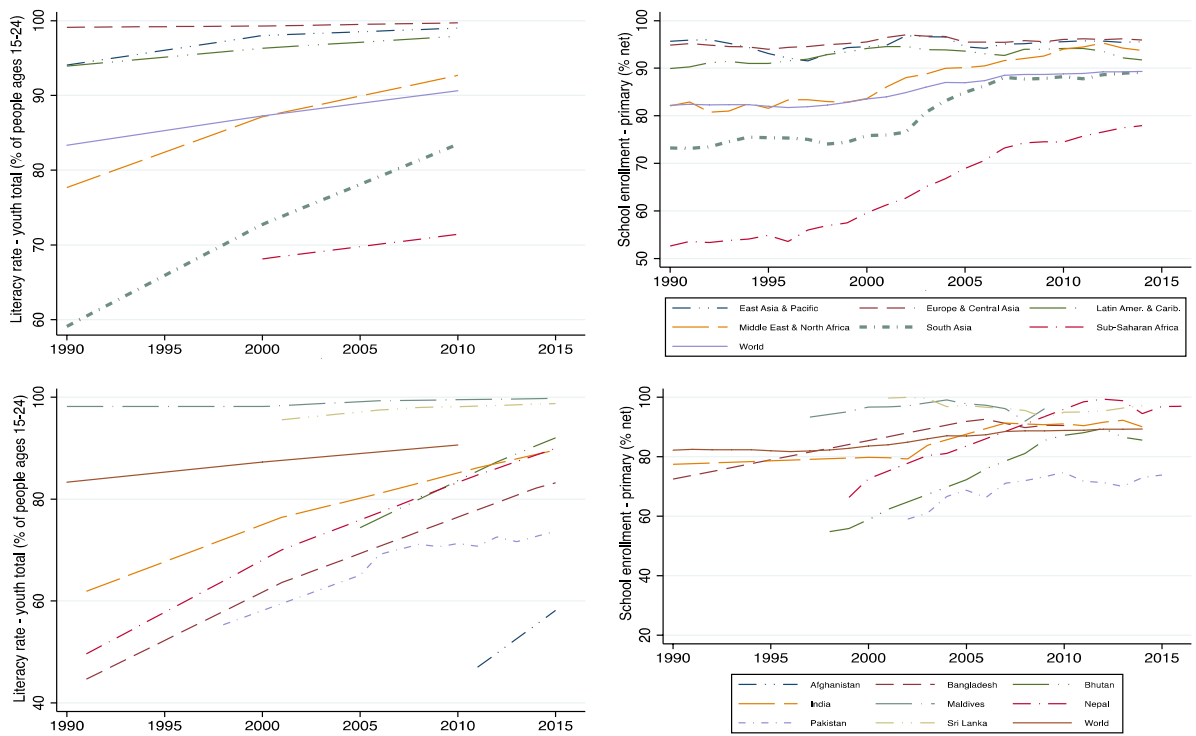

Fig. 4 Universal primary education (MDG Goal 2): selected indicators. Source: World Bank (2017)
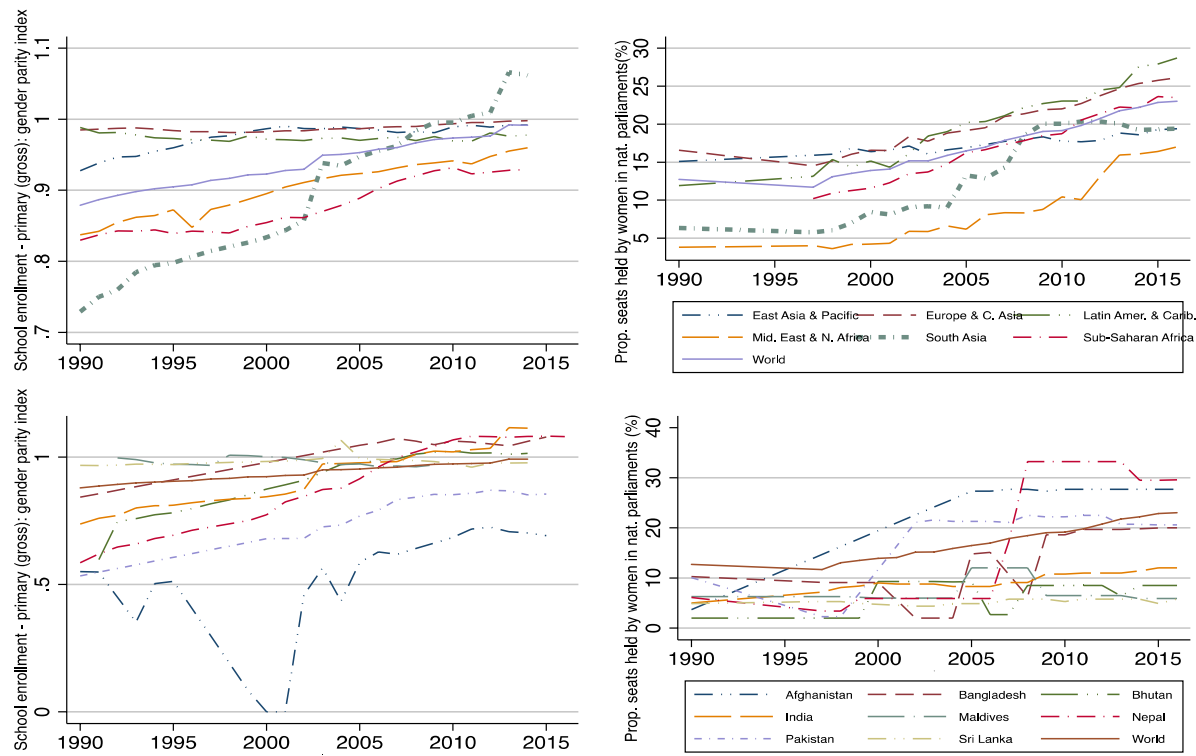

Fig. 5 Gender equality (MDG Goal 3): selected indicators. Source: World Bank (2017) 
primary level. Similar improvements can also be observed also with respect to the share of women holding seats in national parliaments. ${ }^{5}$

Apart from the broad regional comparisons, suggesting that South Asia has made significant progress, there are interesting details on the performance of individual countries. Progress in Universal Primary Education (MDG2) and Gender Equality (MDG3) sees the success of Bangladesh, Sri Lanka ${ }^{6}$ and Nepal driving regional achievements. Furthermore, India and Pakistan's performance in reducing child mortality (MDG4) and improving maternal health (MDG5) was markedly poorer compared to Sri Lanka, Bangladesh and Nepal (El-Saharty et al. 2014; Gayathri and Gangbar 2016). Pakistan was off-track to achieving MDG 2, MDG 3, MDG 4 (Reduce Child Mortality) ${ }^{7}$ and MDG 5 (Improve Maternal Health) targets by 2015 (Government of Pakistan 2013). This seems also true for Afghanistan (The Economist 2016). Ultimately, this initial evidence calls for a closer examination of the variation in countries' progress, trying to uncover what is special about individual contexts and whether there are instances where progress has been exceptional.

\subsection{Why Do We See a Large Variation in MDGs Progress Within South Asia?}

Our discussion in the preceding section shows considerable variation in the rate of progress towards poverty eradication, reducing child mortality, achieving universal primary education and gender equality across countries in South Asia. In this section, we provide brief case-studies of two countries which have seen good progress-Bangladesh and Nepal-and two countries which have seen limited progress-India and Pakistan, identifying key factors that may explain why progress towards the MDGs have been so varied in these countries.

In general, Bangladesh and Nepal have done exceptionally well in MDGs, despite their low-income status (Smith and Neupane, 2011; United Nations 2015). In particular, Bangladesh's progress in social indicators along with others in the region during 1970-2010 have come under the spotlight and been extensively analysed in Mahmud et al. (2013) and Asadullah, Savoia and Mahmud (2014). What explains Bangladesh's success in social development?

According to Sen (1999), human development can happen in two ways: "income-mediated" (through economic growth) and "support-led" pathways (greater public spending on health and education). The surprising aspect of the "Bangladesh model" is that none of the two explanations dominated in explaining the country's social progress. In health indicators, Bangladesh lagged behind other countries of similar income level in child mortality in the 1970s and 1980s, but became a leader in later decades. Excess infant and underfive mortality disappeared by the 1990s, even in the absence of a large-scale reduction in income poverty. Furthermore, Bangladesh immunized $17 \%$ more children against measles compared to other economies at the same level of income during 2006-2010. Similarly,

\footnotetext{
5 Progress has been significant also on improving maternal health, i.e., MDG Goal 5 (trends not reported here). South Asia has steadily reduced maternal mortality, at a faster rate that higher income economies. Improvements are significant also with respect contraceptive prevalence and proportion of births attended by health skilled staff, although less marked.

6 Sri Lanka has been successful in achieving all three targets related to universal primary education (MDG2) and has also reached gender parity in primary education though the proportion of women in the parliament remains very low (MDG3) (Government of Sri Lanka 2015).

7 One exception is "Proportion of Children Under 5 Who Suffered from Diarrhea in the last 30 days".
} 
since the late 1990s, Bangladesh has leapfrogged other countries in terms of female primary and secondary schooling, even after accounting for the difference in the level of economic development.

Asadullah et al. (2014) find limited evidence that such progress was achieved simply through macroeconomic growth or the channel of rising private income. They also find no evidence that Bangladesh's exceptional development progress was a matter of higher public expenditure (i.e., driven by foreign aid or government social spending). If anything, such progress is exceptional because it occurred despite low budgetary allocations, inadequate physical facilities, and extreme poverty; in some cases, progress was achieved within very short time periods. Three concurrent factors may have simultaneously contributed to this "Bangladesh surprise".

First, successive governments maintained an inclusive policy regime, by allowing nongovernmental organizations (NGOs) to play a significant role in reducing fertility and child mortality. This was achieved through the simultaneous use of low-cost solutions and social awareness campaigns by NGOs. In doing so, these bottom-up NGOs initiatives also complemented government maternal and child health programs. Second, the development policies benefited from synergies across the different dimensions of human development. The fertility rate started to fall during the 1980s, when income and schooling levels were very low. This laid the foundations for later progress in health and education indicators. Third, long-term factors (e.g., favourable geography, historical and cultural heritage) might have positively shaped the context of development planning in Bangladesh. For example, high population density facilitated the adoption of low-cost solutions and the spread of good civic practices. In sum, the Bangladeshi experience highlights the importance of adopting low-cost solutions and partnership with non-state providers for social service delivery as two unique pathways to meeting MDGs targets.

Nepal provides a very different model of MDG success than that of Bangladesh, where external factors, such as remittances, have been causal to Nepal's remarkable success in reducing poverty in the MDG period. The sharp increase in migration from Nepal to the Gulf and to South East Asia (where by 2011, one out of every four Nepali households had a migrant abroad) led to a remarkable increase in remittances from one per cent of GDP in the 1990 s to $29 \%$ in 2014, which mostly flowed to poor households (World Bank 2016). In addition, the outflow of predominantly working age adults from rural areas of Nepal led to increases in farm wages, which mostly benefited wage workers in agriculture, the poorest demographic group in the country (ibid.). This, in turn, led to increased demand for nonfarm products, leading to diversification in the rural economy and creation of economic opportunities in non-agricultural activities. However, not all of the poverty reduction in Nepal can attributed to exogenous causes, such as remittance inflows, as the spread of mass education led to declining fertility rates, and falling dependency ratios, which have allowed households in Nepal to maintain living standards that they otherwise would not have been able to enjoy (ibid.). On the other hand, Nepal's success in reducing the under-5 child and maternal mortality rates is attributed to the provision of free basic health care for all citizens and the safe delivery incentive programme (Malla et al. 2011). Policies targeting women, children and vulnerable populations in hard-to-reach places, including cash transfer programmes providing pensions, child grants and single women's allowances, played an important role (UNCTAD 2016).

In contrast, India and Pakistan has had limited progress in MDG goals. In the case of India, in particular, the slow progress in some of the MDGs is surprising, given that the country has witnessed strong economic growth since the 1990s. One important reason has been the weak provision of key public goods that are critical to social development 

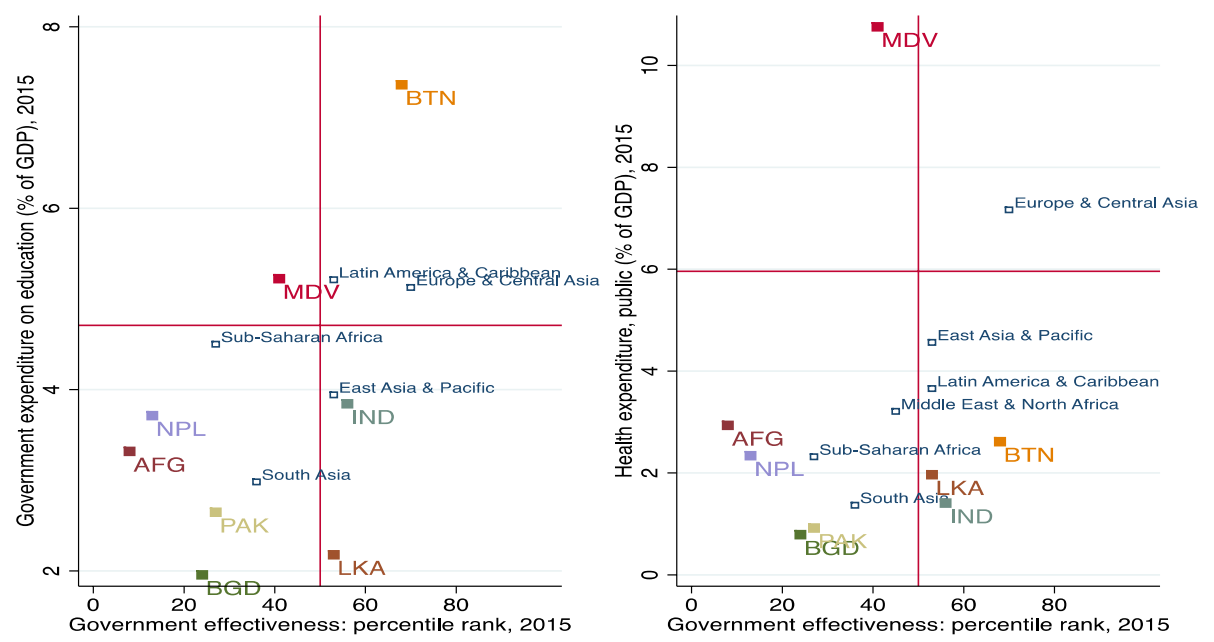

Fig. 6 State capacity, health and education expenditure. Source: World Bank (2017)

progress, such as health services and schooling for the poor. As Pritchett (2009) noted, "the capability of the Indian state to implement programs and policies is weak-and in many domains it is not obvious it is improving. In police, tax collection, education, health, power, water supply—in nearly every routine service — there is rampant absenteeism, indifference, incompetence, and corruption. As this is true of even relatively routine services, even more so for more sophisticated ones like networked irrigation or groundwater management" (pp. 3-4). The core reason for this was the lack of the capability of the state to monitor and hold to account the everyday actions of frontline service providers such as teachers, doctors and nurses (Joshi 2017). In addition, the Indian state has spent significantly less on education and health than other comparable countries-for example, India has one of the lowest shares in the world of public spending on health at 29\% (Joshi 2017). As Dreze and Sen (2013) have argued, there is a need "not only for better health delivery, through institutional change, but also devoting much more resources, as a proportion of GDP, to public expenditure on health" (p. 181).

Pakistan provides a similar story as India in benign state neglect of education and health, with levels of state ineffectiveness that are even lower than of India's (see Fig. 6 below). The Pakistani state also has spent below average levels in education and health, with above average levels of defence spending. Further, high rates of political instability, as well as a highly fractionalised society, has not provided the enabling conditions that can facilitate effective public goods delivery, As Easterly (2003) notes, "Pakistan is the poster child for the hypothesis that a society polarized by class, gender and ethnic group does poorly at providing public services" (p. 465).

The evidence presented here, including country case studies, seems to suggest that country-specific innovative solutions may explain exceptional MDGs achievements. On the other hand, it also suggests that countries' ability to supply public goods and services played an important role in South Asian contexts. The next two sections will discuss the relevance of these factors for achieving SDGs targets in South Asia, as well as assessing where future development progress is predicted to be on the basis of past trends. 


\section{Where is South Asia Expected to be by 2030?}

How will South Asia's development progress unfold in the SDGs period? Based on MDGs trends, this section presents new empirical evidence on where progress in key development outcomes can be expected to be by 2030. This empirical exercise consists of two parts. First we estimate whether, and how fast, differences in development outcomes among countries are narrowing. Then we use such results to produce projections for 2030 on selected SDGs areas.

Following Asadullah and Savoia (2018), we adopt the empirical framework of regressions testing for $\beta$-convergence, which allows obtaining evidence on the speed of progress of each specific development outcome (and to assess whether specific initial conditions influence such progress). In its simplest form, this is a regression, based on cross-section data, of the observed absolute changes over time on a given development measure on the measure's initial values across countries. Let $\Delta P_{i t}$ denote the difference in development outcome $P$ (e.g., poverty measure) in country $i$ observed at both date $t=0$ and $t=D$. A test equation for convergence is then:

$$
\Delta P_{i t}=\alpha+\beta P_{i 0}+\varepsilon_{i} \quad \text { with } \quad I=1, \ldots, N
$$

where $\alpha$ and $\beta$ are parameters to be estimated and $\varepsilon_{i}$ is a zero mean error term. A negative (positive) estimate of the parameter $\beta$ implies that there is convergence (divergence) and the magnitude expresses its speed. ${ }^{8}$ We augment (1) with South Asian country dummies, so to test whether countries' performance is unusual in relation to other countries with similar initial levels of development (i.e., South Asian countries would fare as a response outlier: the dependent variable of interest takes an unusual value for economies with similar characteristics). ${ }^{9}$ This would enable projections that keep into account the effect of country-specific characteristics.

Table 1 reports the results for selected development outcomes in three areas: income poverty, child mortality, and gender parity. We choose conventional measures on incidence and depth of poverty, infant mortality and gender parity in education. What justifies such choice is that they belong to important areas that are common to both the MDGs and SDGs, and so they immediately lend themselves to analyse the links between them. More practically, we choose such variables also because they allow running regressions, and so producing forecasts, for a significant number of countries (including South Asia). Variables and sources are described in the notes to Table 1. The estimates suggest that countries starting with lower development levels tend to experience larger absolute progress than more developed countries, and so "catch up", implying that differences in development levels between countries may be closing. For example, the estimates show that poverty levels have been converging since the 1990, with the coefficients on initial measures both negative and statistically significant at the one per cent level. In all regressions, measures of goodness of fit suggest that initial development levels explain a meaningful part of the variation in subsequent change for each development outcome. To give an appreciation of the

\footnotetext{
8 In particular, Eq. (1) captures the hypothesis of unconditional convergence, according to which countries' development levels converge to one another in the long run independently of their initial conditions, that is, differences are transitory.

9 Its interpretation is equivalent to calculating studentised residuals (which correspond to the t-stat one would obtain by including the country dummy). Easterly (2003) and Asadullah et al. (2014) are examples of previous research adopting this approach.
} 
Table 1 Convergence in selected development outcomes, 1990-2013

\begin{tabular}{|c|c|c|c|c|}
\hline Dep. Variable & $\begin{array}{l}\text { Poverty headcount } \\
\text { ratio at } \$ 1.90 \text { a day } \\
\text { (PPP) (\% pop.) }\end{array}$ & $\begin{array}{l}\text { Poverty gap } \\
\text { at } \$ 1.90 \text { a day } \\
(\mathrm{PPP})\end{array}$ & Infant mortality rate & $\begin{array}{l}\text { Gender parity index, } \\
\text { primary enrollment } \\
(\%)\end{array}$ \\
\hline Initial value & $\begin{array}{l}-0.198 * * * \\
(0.063)\end{array}$ & $\begin{array}{l}-0.361 * * * \\
(0.075)\end{array}$ & $\begin{array}{l}-0.392 * * * \\
(0.035)\end{array}$ & $\begin{array}{l}-0.719 * * * \\
(0.046)\end{array}$ \\
\hline Afghanistan dummy & & & $\begin{array}{l}6.827 * * \\
(2.913)\end{array}$ & $\begin{array}{l}-12.688 * * * \\
(2.395)\end{array}$ \\
\hline Bangladesh dummy & $\begin{array}{l}7.522 \\
(4.909)\end{array}$ & $\begin{array}{l}2.043 \\
(3.074)\end{array}$ & $\begin{array}{l}-18.695 * * * \\
(2.216)\end{array}$ & \\
\hline Bhutan dummy & & & $\begin{array}{l}-12.170^{* * * *} \\
(1.967)\end{array}$ & $\begin{array}{l}10.161 \text { *** } \\
(1.217)\end{array}$ \\
\hline India dummy & $\begin{array}{l}4.015 \\
(4.218)\end{array}$ & $\begin{array}{l}1.432 \\
(2.145)\end{array}$ & $\begin{array}{l}-4.295^{* *} \\
(1.991)\end{array}$ & $\begin{array}{l}9.091 * * * \\
(0.959)\end{array}$ \\
\hline Maldives dummy & & & $\begin{array}{l}-25.710^{* * * *} \\
(1.232)\end{array}$ & \\
\hline Nepal dummy & & & $\begin{array}{l}-17.124 * * * \\
(2.132)\end{array}$ & $\begin{array}{l}18.699 * * * \\
(1.513)\end{array}$ \\
\hline Pakistan dummy & $\begin{array}{l}-14.489 * * * \\
(4.613)\end{array}$ & $\begin{array}{l}-13.484 * * * \\
(2.890)\end{array}$ & $\begin{array}{l}9.668 * * * \\
(2.643)\end{array}$ & \\
\hline Sri Lanka dummy & $\begin{array}{l}-10.280 \text { *** } \\
(2.296)\end{array}$ & $\begin{array}{l}-2.054 * * * \\
(0.717)\end{array}$ & $\begin{array}{l}-1.638^{* * * *} \\
(0.580)\end{array}$ & \\
\hline Constant & $\begin{array}{l}-5.578^{* * *} \\
(1.417)\end{array}$ & $\begin{array}{l}-1.495^{* *} \\
(0.615)\end{array}$ & $\begin{array}{l}-0.802 \\
(1.075)\end{array}$ & $\begin{array}{l}70.968 * * * \\
(4.548)\end{array}$ \\
\hline F-stat & $4.00 * * *$ & $10.86^{* * * *}$ & $46.25 * * *$ & $89.44 * * *$ \\
\hline Adj. $\mathrm{R}^{2}$ & 0.20 & 0.45 & 0.69 & 0.79 \\
\hline Obs & 62 & 62 & 186 & 143 \\
\hline RMSE & 12.74 & 8.23 & 10.27 & 4.88 \\
\hline
\end{tabular}

The dependent variable is the 1990-2013 absolute change of each outcome. The final and initial values are taken at 2013 and 1990 circa, to obtain the largest number of observations. Regressions are estimated by Ordinary Least Squares. Symbols * ** and *** stand for significant at 10, 5 and $1 \%$ respectively. Poverty headcount ratio at $\$ 1.90$ a day is the percentage of the population living on less than $\$ 1.90$ a day at 2011 international prices. Poverty gap at $\$ 1.90$ a day (2011 PPP) is the mean shortfall in income or consumption from the poverty line $\$ 1.90$ a day (counting the nonpoor as having zero shortfall), expressed as a percentage of the poverty line. Infant mortality rate is the number of infants dying before reaching one year of age, per 1,000 live births in a given year. Gender parity index for gross enrollment ratio in primary education is the ratio of girls to boys enrolled at primary level in public and private schools. All variables are from the World Development Indicators (World Bank 2017)

speed of convergence in South Asia, consider the poverty headcount ratio at $\$ 1.90$ a day in 1990 in India (scoring 81.73). According to Table 1 estimates, the expected reduction in poverty headcount will be $-5.578-0.198 \times 81.73=-21.74$ percentage points. Sri Lanka, starting from a lower level of initial poverty, is predicted to have a smaller reduction (of -15.37 percentage points). This is indicative of significant convergence process, although a slow one, where differences in poverty levels may still persist for a long time.

Importantly, Table 1 results provide also a quantitative appreciation of the exceptionality of South Asia's progress. Compared to other countries at the same initial level, with the 


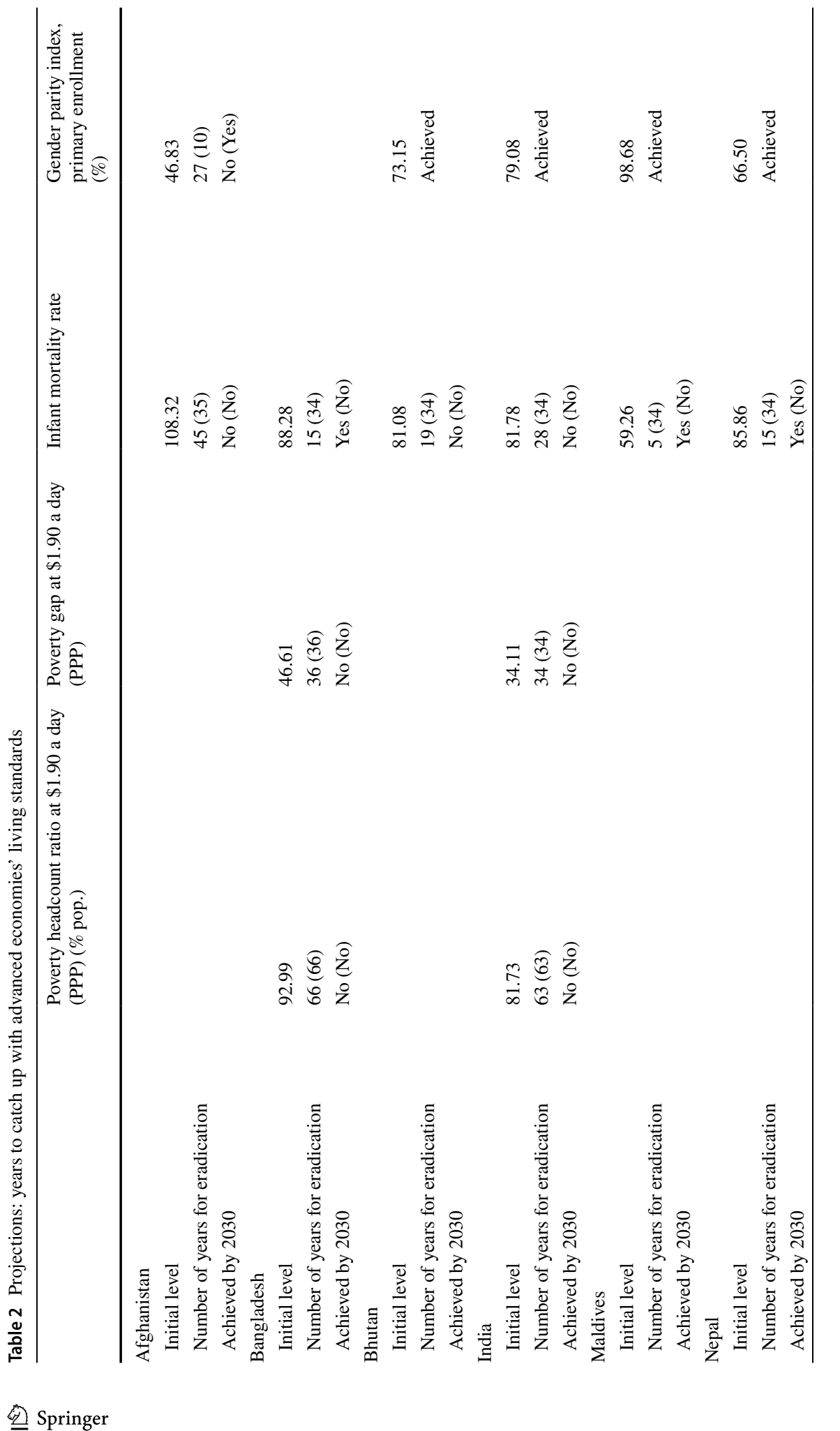




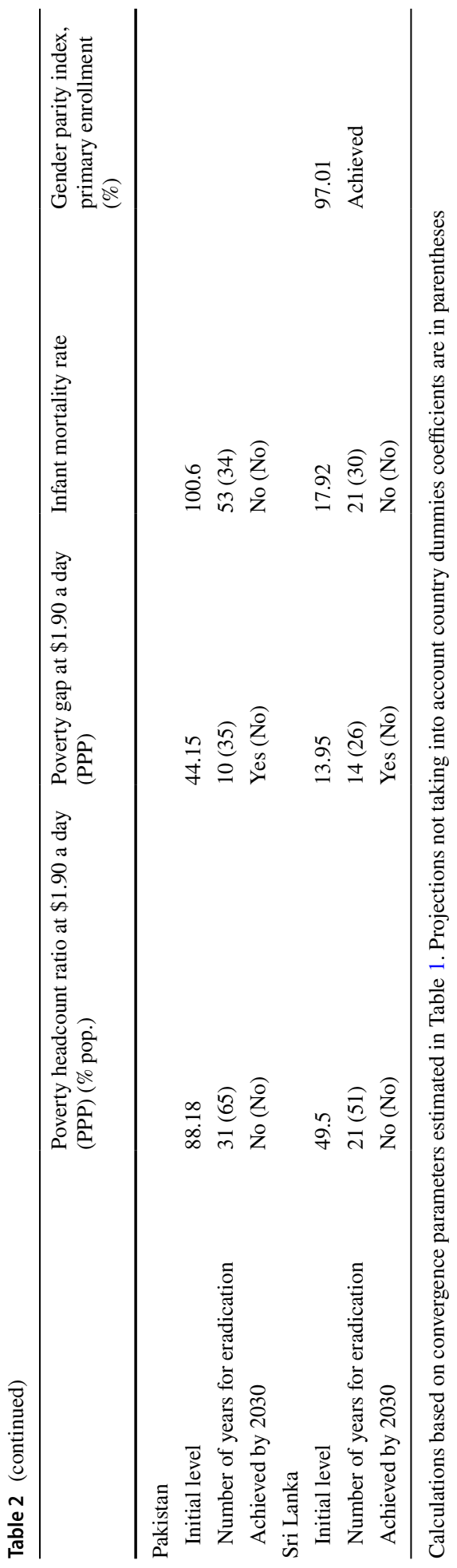


exception of Afghanistan and Pakistan, South Asian countries experienced an unusually higher reduction in infant mortality rates and increase in the gender parity index at primary level. Sri Lanka had an unusually higher reduction in income poverty outcomes during 1990-2013, while Bangladesh and India have progressed showing no sign of exceptionality in this respect.

What does this imply in terms of future progress?Table 1 results provide the basis for the second part of this empirical exercise. We use the estimated speed of convergence to provide projections for each of the above development indicators in South Asia, given their initial levels. Assuming the converge trend for each MDG target above stays unchanged and that countries keep progressing at the same rate, Table 2 calculates how many years beyond 2013 it will take to reach the 'developed' status, i.e., how long it will take to eradicate income poverty and infant mortality, ${ }^{10}$ and achieve gender parity at primary level.

The projections suggest four broad considerations. For the populous South Asian countries for which we can provide estimates, eradicating income poverty may still be a long process, which will continue beyond the SDGs period. For example, if India keeps reducing income poverty and infant mortality at the same rate, it is predicted to miss such targets at the end of the SDGs period. The same simple arithmetic suggests similar conclusions for Bangladesh and Pakistan, although poverty projections for Pakistan are more difficult to interpret. ${ }^{11}$ Secondly, progress in eradicating infant mortality is projected to vary substantially across the region, suggesting that success or failure by the end of the SDGs period seems to depend on country-specific factors. Thirdly, progress on the gender parity index in primary enrolment seems to be such that most South Asia countries have achieved the target, with the exception of Afghanistan.

Finally, it is important to note that the foregoing illustrations would be different had South Asian countries fit the 'typical' behaviour. For example, without keeping into account country dummies, infant mortality eradication would be projected to arrive within remarkable similar periods well after the end of the SDGs, even when starting at similar initial levels of development (see projections in parentheses). Similar conclusions apply to other development outcomes in Table 2. The above empirical exercise ultimately suggests that context may be important, since we have instances where progress has been exceptional. This prompts us to look more closely at such variation in development progress, trying to identify which conditions or country-specific characteristics may explain it.

\footnotetext{
10 Target 3.2 of SDG 3 requires "all countries aiming to reduce neonatal mortality to at least as low as 12 per 1000 live births and under-5 mortality to at least as low as 25 per 1000 live births". See https://susta inabledevelopment.un.org/sdg3, consulted on 11/10/2019.

11 The Pakistani case demands caution with respect to income poverty reduction. Khan et al. (2015), analyzing official poverty statistics between 1990 and 2010, argue that poverty estimates may be biased because of both technical flaws and political pressure affected measurement. Hence, it seems difficult to reach a definitive conclusion on the extent of poverty reduction and, by implication, on the extent of progress on MDG Goal 1. All the data used here is publicly available in the World Bank's World Development Indicators, which is subject to routine quality checks (see https://datatopics.worldbank.org/world-devel opment-indicators/stories/world-development-indicators-the-story.html, consulted on 10th October 2019) and routinely used for MDGs and SDGs monitoring.
} 


\section{SDGs Challenges: State Capacity and Public Spending}

The previous sections showed that social progress has been significant in the region, but the MDGs achievements have not been uniform across the different countries or, indeed, across all dimensions. Moving beyond stylised facts, projections indicated that SDGs progress might show substantial variation across the region and that country context may be important. Now we look at the conditions that may hinder or facilitate the design and effectiveness of development policies in the SDGs period. In this section, we first assess how South Asian countries are positioned in terms of resources and states' ability to govern the process of development at the start of the SDGs period, providing new quantitative evidence simulating their impact. Then we discuss such challenges with respect to achieving SDGs 1, 4, 5 and 8, focussing on how country-specific solutions played for South Asia's MDGs achievements.

\subsection{Public Spending and Effective States: Do they matter?}

What could accelerate SDGs progress? Here we concentrate on two important ingredients: how the region is positioned in terms of public resources devoted to development and its countries' ability to administer public policies. The first one relates to public spending on health and education and it will be increasingly relevant to the pursuit of the SDGs, as Goal 17 explicitly refers to the mobilisation of domestic recourses. Indeed, public spending on health and education is considered one of the two key pathways to human development (Sen 1999), the other one being the "income-mediated" pathway, which works through economic growth and has seen a slowdown at global level. The second ingredient relates to the type and functioning of institutions a country has, which is seen as a structural factor affecting the functioning of both types of pathway to development (e.g., Dimova and Savoia 2016) and is reflected in SDG Goal 16 on "effective and accountable institutions". In particular, the recent debate has emphasised that having effective states is a fundamental prerequisite to deliver policies benefitting the population at large and is increasingly considered one the drivers of long-term economic development (see Savoia and Sen 2015).

Figure 6 plots government expenditure on health and education for South Asian countries and macro regions, against a popular governance quality indicator allowing comparisons for the largest number of countries, Government effectiveness, proxying for the level of state capacity. ${ }^{12}$ Both are taken immediately before the start of the SDGs period. The figure also marks with a line the average level of public spending and the middle Government effectiveness ranking, so to divide the plan in four quadrants. Ideally, one would want to be in the quadrant of high public spending on health and education and high state capacity, so that the benefits of the "support-led" channels for the SDGs are likely to be maximised (everything else being equal). But South Asia, as an aggregate, fares in the quadrant of low public spending on health and education and low state capacity. This is an unfavourable starting point, suggestive of a significant disadvantage.

\footnotetext{
12 Government Effectiveness captures perceptions of the quality of public services, the quality of the civil service and the degree of its independence from political pressures, the quality of policy formulation and implementation, and the credibility of the government's commitment to such policies (World Bank 2017). Percentile rank indicates the country's rank among all countries covered by the aggregate indicator, with 0 corresponding to lowest rank, and 100 to highest rank.
} 


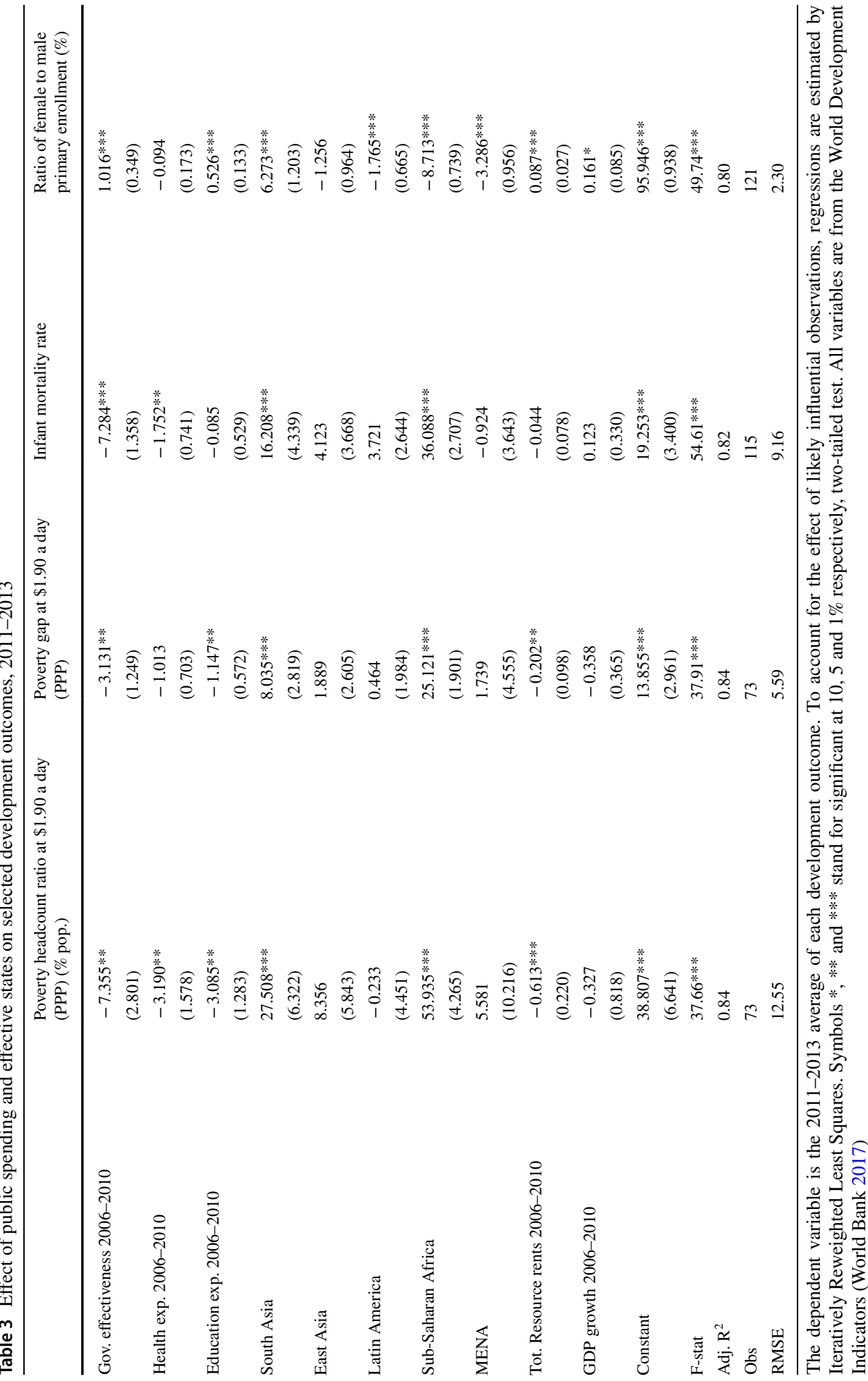


Looking at individual countries, we observe that only Bhutan is well positioned, followed by India and Sri Lanka, having a relative advantage over the rest of the region in terms of governance. Afghanistan, Nepal, Pakistan and Bangladesh show, instead, a relative governance deficit, suggesting future development policy to enhance the pursuit of SDGs targets would require pushing governance reforms while at the same time using public spending.

To illustrate further the policy relevance of effective states and public expenditure on health and education, we undertake a simple empirical exercise. In Table 3, we regress the same selected development indicators, common to the MDGs to the SDGs, against standard World Bank measures on Government effectiveness and public expenditure on health and education as a share of GDP, including as controls a full set of regional dummies, the average rate of GDP growth, and the average level of natural resources income. This set of results is suggestive of a significant association between key SDGs outcomes and state capacity, health and education expenditure. As each regression explains substantial variation of the outcomes considered, this is also a useful base to simulate the likely impact in the region.

We therefore use the estimates in Table 3 to calculate the predicted effect of changes in Government effectiveness, health and education expenditure on each development outcome, under different scenarios. For each of the three policy variables, the first scenario is a one standard deviation increase from the South Asia sample average. The second type of scenario hypothesises rising to the level of other regions: (i) an increase to the level of state capacity of East Asia, traditionally considered an area where states were instrumental to development; (ii) an increase in health and education expenditure to the level of Latina America, an emerging region which seems to rely more on public expenditure, compared to most developing regions. Table 4 presents the results.

First, the estimates suggest that improving state capacity has a sizable payoff for all development outcomes considered. Although reforming state institutions may be a longterm and challenging exercise, because of resistance due to the inherent distributive implications of such reforms (e.g., Bardhan 2005), these estimates suggest that it may be worth the effort and so provide an argument to build political support. Second, public expenditure on health and education seems to deliver the largest reduction in the development outcomes considered. Third, because the challenge will be to find the resources to support increased public spending without compromising the long-run stability of public finances, a combination of improvements in state capacity and an incrementally greater injection of health and education expenditure seems an attractive option. It would still deliver significant benefits, while being affordable at the same time.

Based on the MDGs regional experience, the remainder of this section will discuss how the challenges of improvements in state capacity and mobilising resources for health and education expenditure may be critical to the region's progress on the goals of No Poverty (SDG1) and Inclusive Growth (SDG8), Quality Education (SDG4), and Gender Equality (SDG5). 


\subsection{Achieving "No Poverty" and "Inclusive Growth": SDGs 1 and 8}

Ending extreme poverty by 2030 would require GDP growth acceleration to ensure private income growth. ${ }^{13}$ But how likely is it? Given the global economic uncertainties and growth slowdown in the region, such growth acceleration is unlikely. In this context, poverty alleviation programs and social safety net schemes will need to be prioritised. However, the impact of state-led initiatives has been less than satisfactory for two reasons. First, budgetary allocations are low by regional standards, limiting the scope for social expenditure-led approach. Second, countries in the region are affected by deep-rooted governance problems and regressive subsidy systems (Asadullah et al. 2014; Rama et al. 2015). Poor governance has led to mis-targeting and leakages undermining the effectiveness of social safety net programs throughout South Asia. ${ }^{14}$

Despite governance problems in the social sectors, Bangladesh has done better by innovating low-cost solutions to tackle various development problems, such as microcredit programs. Yet hard evidence on the efficacy of microfinance to eradicate poverty is missing (Banerjee 2013). One promising alternative approach is unconditional transfers of assets to the extreme poor, which is viewed as a form of "big push" for the financially poor households. Similar to microfinance, BRAC's "Targeting the Ultra Poor" program target transfers to women. This approach has been replicated in several countries in South Asia and Africa (Banerjee et al. 2015). While program impact is absent in South Indian context in terms of lasting net impact on income or asset accumulation (Bauchet et al. 2015), evidence based on randomized contract evaluation in Bangladesh and Pakistan suggests that the "poverty graduation" model is effective (Bandiera et al. 2017). However, there are some concerns over the long-term sustainability of the program impact (Buera et al. 2016; Asadullah and Ara 2016; Roy et al. 2015).

Access to physical capital or credit aside, human capital development is critical for inclusive growth. Yet inequality of social opportunities (e.g., educational attainment) is a major challenge to inclusive growth in South Asia (Asadullah and Yalonetzky 2012) and remains an important explanation for poverty among the socially disadvantaged groups (Gardin 2016). Partnerships with citizen-led groups, faith-based providers and NGOs proved critical in equalizing social opportunities during the MDGs era in Bangladesh so that inequalities in social development indicators were lower compared to India. At the same time, there is concern about the quality of service delivered. In Pakistan and India, for-profit private schools have created new forms of exclusions. Moreover, non-state providers have favoured locations for service delivery that have benefited from public investment in India, Bangladesh and Pakistan. In general, there is limited evidence that the composition of private school students is becoming equitable in South Asia (Pal 2010; Asadullah 2016; Andrabi et al. 2013).

\footnotetext{
13 The importance of macroeconomic growth in poverty reduction in the region is recognised (Bhagwati and Panagariya 2014; Datt et al. 2016; Joshi 2017). However, fast-growing South Asian economies in recent decades have been unable to replicate the Asian model of "growth with equity" (Jain-Chandra et al. 2016; Rama et al. 2015). Multidimensional lenses suggest slow poverty reduction progress (Cruz et al. 2015; Alkire and Seth 2015).

14 Examples of exceptions (i.e., well-targeted social protection programs) include the Benazir Income Support Program in Pakistan (Rama et al. 2015; Government of Pakistan 2013).
} 


\subsection{Achieving “Quality Education”: SDG4}

Most governments in South Asia have succeeded in closing school enrolment rate gaps vis-à-vis other developing regions. In Bangladesh, innovative schemes such as Food for Education, the Female Secondary School Assistance Program (FSSAP) and the secondchance school model of BRAC have been instrumental in improving access and in reducing gender inequality in educational participation. However, enrolment growth did not translate into learning outcomes because of flat 'learning profile', i.e., the weak relationship between years of schooling completed and literacy (Pritchett 2014; Asadullah and Chaudhury 2015; Kaffenberger and Pritchett 2016; Sandefur et al. 2016; Asadullah and Savoia 2018). South Asia, as a region, is undergoing a learning crisis (UNESCO 2014; World Bank 2018). Data on women's literacy indicates that in India, Bangladesh, Pakistan and Nepal, learning profiles have not improved over time (Pritchett and Sandefur 2017). The SDG target of universal literacy is unlikely to be achieved only through the provision of universal primary school completion.

The problem of low school quality cannot be overcome simply with more investment in terms of physical inputs. One meta-analysis of evaluations of educational interventions in South Asia find that programs targeting teachers or schools are more effective at improving learning outcomes instead of schemes that increase the demand for education in households and communities (Asim et al. 2016). A more comprehensive review of the international evidence suggests that structured pedagogy schemes (e.g. development of subject-specific contents, new teaching and learning materials, and training programs for teachers in the delivery of the new content) consistently and positively impact learning outcomes (Snilstveit et al. 2016). At the same time, there is a growing concern against the practice of mere adoption of models and interventions that worked in other countries. Transforming failing schools will require developing context-driven solutions through promoting flexible policies that allow education planners and school principals to experiment with their own approaches and solutions (Pritchett 2014).

\subsection{Achieving "Gender Inequality": SDG5}

South Asian countries, particularly Bangladesh, India, Nepal, Afghanistan and Pakistan, share a dismal record in other important aspects of gender equality, such as violence against women and under-age marriage of girls (UNDP 2010; Solotaroff and Pande 2014). The region has the highest incidence of girls marrying during childhood or early adolescence (UNICEF 2014). During the MDG era, child marriage was interpreted as a by-product of poverty and low schooling of girls (Khanna et al. 2013). While household wealth is negatively linked with child marriage in South Asia (Male and Wodon 2017), the decline in prevalence has been less than proportionate to fall in income poverty. Similarly, various social programmes implemented in Bangladesh and India led to significant reductions in infant and child mortality and fertility while also increasing secondary school participation. The FSSAP scheme in Bangladesh also required girls to be in school and stay out of marriage. In India, as many as 15 states launched conditional transfer programs to tackle the problem (Sekher 2012). Yet India and Bangladesh did not see a large-scale decline in child marriage.

In part, interventions involving financial transfers such as conditional transfer scheme overlooked the role of social constraints and customs. Even with provisions of financial transfers, households in India continue to opt for early marriage of their daughters by simply tweaking the marriage contract to secure the financial rewards promised by the intervention (Amin et al. 


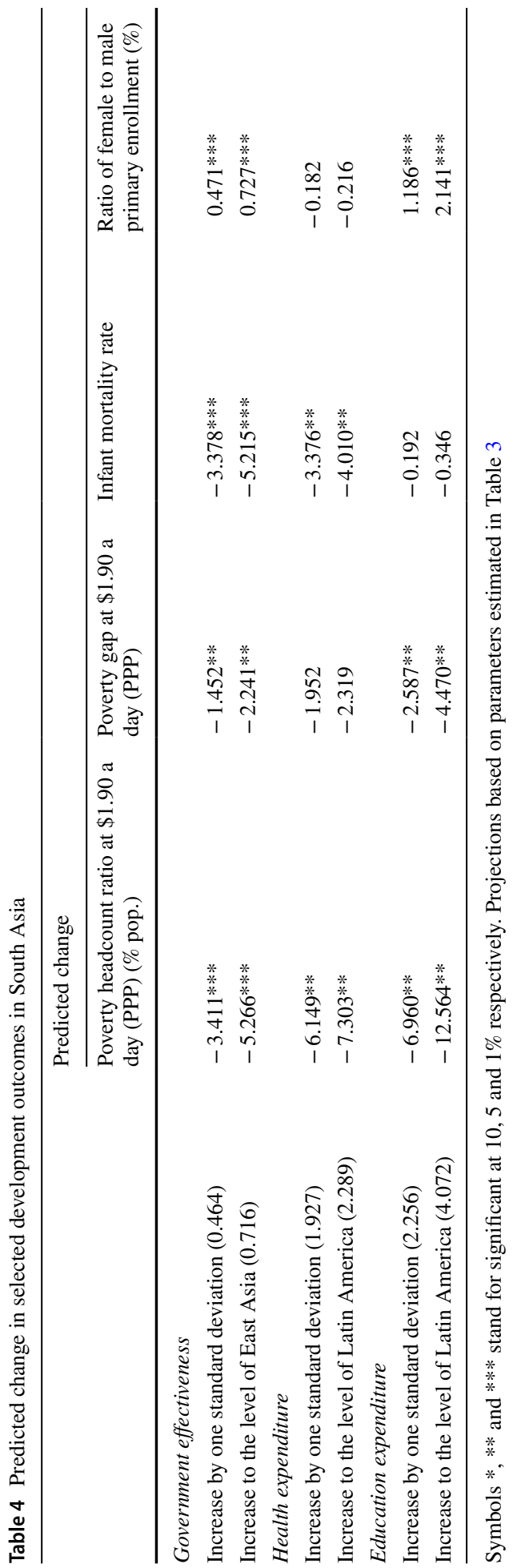


2017). Legal solutions to addressing issues of prevention and protection have so far failed. Efforts to increase the minimum marriageable age from 16 to 18 have faced religious opposition in Pakistan, while the Bangladesh government has passed a new legislation permitting marriages of girls aged below 18 under special circumstances. But state capacity plays a role too. Indeed, existing national policies that limit child marriage are routinely undermined by weak implementation and lax enforcement (Asadullah and Wahhaj 2016). Birth registration records can be manipulated through bribes. Similarly, administrative shortfalls can undermine programs eradicating child marriage, such as conditional cash transfer programs in India (Gupta et al. 2008).

\section{Conclusions and Policy Implications}

This paper has revisited South Asia's development progress during the MDGs period, providing new evidence on the institutional and policy challenges for SDGs progress in the region deriving from the MDGs experience. We have found that the MDGs period saw steady improvement in social indicators, showing evidence of convergence of South Asia with richer regions in many important outcomes. At the same time, we find that South Asia's performance in achieving the MDGs has not been stellar. Further, there is a long way to go in the "Leaving No One Behind" agenda in South Asia, as our projections indicate that important milestones, such as eradicating income poverty, may not occur by 2030 . We argue that two important factors behind South Asia's rather mediocre prospects towards achieving the SDGs is the limited fiscal resources that have been spent on education and health and the limited effectiveness of the state in delivering public goods. We show that, if South Asia's government spending on education and health and state capacity were to rise to levels witnessed in other developing regions (such as Latin America or East Asia), South Asia would make significant progress in achieving the SDGs. What lessons does our analysis hold for South Asia's policy makers as they strive to achieve the "Leaving No One Behind" agenda?

First, a step-wise approach (e.g., growth first, governance reforms later) is unlikely to work. For example, as highlighted by the contrasting experience of Bangladesh and India, programs tackling child marriage and improving women's participation rate in the economy will fail without improved state capacity (e.g., effective birth registration and enforcements of the law guaranteeing physical security of women in the public space).

Second, as SDGs are more ambitious than MDGs, both goal-specific and cross-cutting interventions are needed. However, the search for specific, scalable solutions to end poverty remains elusive. As the experience of the MDGs era shows, without the provision for rigorous evaluation and progress monitoring, less effective schemes can continue for too long without much result. While the practice of ranking alternatives based on costs and benefits has promise, this too can be misleading when benefits are long-term and less tangible (e.g., improved confidence and empowerment deriving from an unconditional transfer scheme cannot be adequately monetised).

Third, during the MDGs era, South Asia has overemphasised single-focused policy prescriptions (e.g., improved access to education through better physical infrastructure at school), that too with minimal budgetary commitment. In the context of SDG 4, retaining the same would risk reproducing the past pattern of schooling without learning (Pritchett 2014; World Bank 2018). While an expanded coverage of health and education services under state provision is critical, governments must learn best practices from non-state 
providers. However, partnership with non-state actors can also involve costly qualityquantity trade-offs.

Fourth, scope for an "income mediated" approach to SDG1 (on ending poverty) seems limited in the coming decades. Rapid GDP growth during 1990-2010 has been a powerful driver of extreme poverty reduction in South Asia, but there is no guarantee this will continue during the SDGs. In the Bangladesh context, for instance, reducing poverty rate to $14 \%$ by 2021 requires an economic growth rate of at least 8 percent (Gimenez et al. 2014). With global economic slowdown, this is unlikely to be achieved. Emphasis, therefore, has to be also on an expenditure-led approach. Growth alone will not be sufficient to eradicate extreme poverty by 2030. Strong livelihood interventions in the form of "mini Big Push" will be critical (Sen and Ali 2015).

Fifth, SDGs are more resource-intensive than the MDGs, particularly with the inclusion of goals 7, 9, 11 and 13. Yet south Asian countries are characterised by wide gaps in basic infrastructure, such as access to drinking water and sanitation (SDG6). Within the region, only Bangladesh has been an exception to this pattern because of its geography (dense settlement), reliance on low-cost solutions and partnership with non-state actors. However, this model is not sustainable. Many of the countries have graduated into lower middleincome category so that scarce aid money is less likely to flow into the region. With a decline in the aid inflow, enhancing the pursuit of SDGs through improved capacity to raise public resources domestically is a key challenge for the region. According to one estimate, public investments between 10 and 20\% of GDP are required in South Asia in addition to around $\$ 5$ trillion for closing infrastructure gaps by 2030 . However, the region has one of the lowest tax-to-GDP ratios in the world. The potential for increasing domestic resources through expanding the tax base also hinges on tax reforms and efficient tax administration departments. Relying on private sector development and broadening of the tax base, instead of external finance, may help avoid indebtedness while closing the investment-savings gap (UNCTAD 2016).

Our overall message is that in the SDGs context, limited state capacity, as well as limited fiscal commitment, could prove to be obstacles collectively undermining much-needed resources to achieve the SDGs targets in South Asia. In particular, with the slowdown in macroeconomic growth in the region, future progress will increasingly depend on increase in social spending and improvement in public goods delivery systems. This means that, in order to consolidate the gains made during the MDGs era, the challenge for South Asia lies in addressing multiple forms of public governance failures; therefore progress in SDG16 may simultaneously accelerate progress in SDGs $1,4,5$ and 8.

Open Access This article is licensed under a Creative Commons Attribution 4.0 International License, which permits use, sharing, adaptation, distribution and reproduction in any medium or format, as long as you give appropriate credit to the original author(s) and the source, provide a link to the Creative Commons licence, and indicate if changes were made. The images or other third party material in this article are included in the article's Creative Commons licence, unless indicated otherwise in a credit line to the material. If material is not included in the article's Creative Commons licence and your intended use is not permitted by statutory regulation or exceeds the permitted use, you will need to obtain permission directly from the copyright holder. To view a copy of this licence, visit http://creativecommons.org/licenses/by/4.0/.

\section{References}

Alkire, S., \& Robles, G. (2016). Global multidimensional poverty index 2016. OPHI Briefing 41, University of Oxford. 
Alkire, S., \& Seth, S. (2015). Multidimensional poverty reduction in India between 1999 and 2006: Where and how? World Development, 72, 93-108.

Amin, S., Asadullah, M. N., Hossain, S., \& Wahhaj, Z. (2017). Can conditional transfers eradicate child marriage? Economic and Political Weekly, 52(6), 26-28.

Andrabi, T., Das, J., \& Khwaja, A. (2013). Students today, teachers tomorrow: Identifying constraints on the provision of education. Journal of Public Economics, 100, 1-14.

Asadullah, M. N. (2016). Do pro-poor schools reach out the poor? Location choice of BRAC and ROSC schools in Bangladesh. Australian Economic Review, 49(4), 432-452.

Asadullah, M. N., \& Ara, J. (2016). Evaluating the long-run impact of an innovative anti- poverty program: Evidence using household panel data. Applied Economics, 48(2), 107-120.

Asadullah, M. N., \& Chaudhury, N. (2015). The dissonance between schooling and learning. Comparative Education Review., 59(3), 447-472.

Asadullah, M. N., \& Savoia, A. (2018). Poverty reduction during 1990-2013: Did millennium development goals adoption and state capacity matter? World Development, 105, 70-82.

Asadullah, M. N., \& Wahhaj, Z. (2016). Child marriage law and freedom of choice: The battle against early marriage in Bangladesh. Economic and Political Weekly, 51(3), 16 Jan.

Asadullah, M. N., Savoia, A., \& Mahmud, W. (2014). Paths to development: Is there a Bangladesh surprise? World Development, 62, 138-154.

Asadullah, M. N., \& Yalonetzky, G. (2012). Inequality of educational opportunity in India: Changes over time and across states. World Development, 40(6), 1151-1163.

Asim, S., Chase, R. S., Dar, A., \& Schmillen, A. (2016). Incentives for education in South Asia: Findings from a decade of impact evaluations. In World Bank Research Observer, published online on October 23. https://doi.org/10.1093/wbro/lkw006

Bandiera, O., Burgess, R., Das, N., Gulesci, S., Rasul, I., \& Sulaiman, M. (2017). Labor markets and poverty in village economies. Quarterly Journal of Economics, 132(2), 811-870.

Banerjee, A. V. (2013). Microcredit under the microscope: What have we learnt in the last two decades, what do we need to know? Annual Review of Economics, 5, 487-519.

Banerjee, A., Duflo, E., Goldberg, N., Karlan, D., Osei, R., Parienté, W., Shapiro, J., Thuysbaert, B., Udry, C. (2015). A multifaceted program causes lasting progress for the very poor: Evidence from six countries. Science, https://doi.org/10.1126/science.1260799

Bauchet, J., Morduch, J., \& Ravi, S. (2015). Failure vs. displacement: Why an innovative anti-poverty program showed no net impact in South India. Journal of Development Economics, 116(3), 1-16.

Bardhan, P. (2005). Scarcity, conflict and cooperation. Cambridge: MIT Press.

Bhagwati, J., \& Panagariya, A. (2014). Why growth matters: How economic growth in India reduced poverty and the lessons for other developing countries. Public Affairs.

Buera, F. J., Shin, Y., Kaboski, J. P. (2016). Taking stock of the evidence on micro-financial interventions. In The economics of asset accumulation and poverty traps. National Bureau of Economic Research.

Cruz, M., Foster, J., Quillin, B., \& Schellekkens, P. (2015). Ending extreme poverty, sharing prosperity: Progress and policies. Washington: World Bank.

Datt, G., Ravallion, M., \& Murgai, R. (2016). Growth, urbanization and poverty reduction in India. In NBER working paper 21983.

Dimova, R., \& Savoia, A. (2016). Institutions: Evolution, path dependency, anachronisms and impact. The Journal of Development Studies, 52(2), 161-165.

Dreze, J., \& Sen, A. (2013). An Uncertain Glory: India and its Contradictions. Princeton: Princeton University Press.

Easterly, W. (2003). The political economy of growth without development: A case study of Pakistan. In D. Rodrik (Ed.), In search of prosperity; analytical narratives on economic growth. Princeton: Princeton University Press.

Elder, M., Bengtsson, M., \& Akenji, L. (2016). An optimistic analysis of the means of implementation for Sustainable Development Goals: Thinking about goals as means. Sustainability, 8, 961-986.

El-Saharty, S., Ohno, N., Sarker, I., Secci, F., Ul Haq, I., \& Kashif, A. (2014). Pakistan: Maternal and reproductive health at a glance. Washington: World Bank.

Fukuda-Parr, S., \& Hulme, D. (2011). International norm dynamics and 'the end of poverty': Understanding the Millennium Development Goals (MDGs). Global Governance, 17(1), 17-36.

Gardin, C. (2016). Poverty and ethnicity in Asian countries. In ADBI working paper No. 624.

Gayathri, K., \& Gangbar, J. (2016). Child and maternal health and nutrition in South Asia-lessons for India (mimeo).

Gimenez, L., Jolliffe, D., \& Sharif, I. (2014). Bangladesh, a middle income country by 2021: What will it take in terms of poverty reduction? Bangladesh Development Studies, 37(1\&2), 1-20. 
Government of Pakistan. (2013). Pakistan Millennium Development Goals report 2013 summary Planning Commission., Islamabad: Government of Pakistan.

Government of Sri Lanka. (2015). Sri Lanka Millennium Development Goals country report 2014. Government of Sri Lanka, March 2015.

Gupta, S. D. et al. (2008). Knot ready: Lessons from India on delaying marriage for girls. International Centre for Research on Girls (ICRW). https://www.icrw.org/wp-content/uploads/2016/10/Knot-Ready -Lessons-from-India-on-Delaying-Marriage-for-Girls.pdf.

Jain-Chandra, S., Kinda, T., Kochhar, K., Piao, S., Schauer, J. (2016). Sharing the growth dividend; analysis of inequality in Asia. In IMF working papers 16/48. International Monetary Fund.

Jones, T. M. (2017). Accountability for development cooperation under the 2030 agenda. In German development institute discussion paper 10/2017.

Joshi, V. (2017). India's long road: The search for prosperity. Oxford: Oxford University Press.

Khan, A., Naveed, A., Samman, E., Sarwar, M. B., \& Hoy, C. (2015). Progress under scrutiny: Poverty reduction in Pakistan. In ODI research reports and studies. Retrieved from: https://www.odi.org/publi cations/9957-pakistan-extreme-poverty-measuring-inequality-statistics.

Kaffenberger, M., \& Pritchett, L. (2016). Schooling completion and learning: New evidence from the financial inclusion insights data.

Khanna, T., Verma, R., \& Weiss, E. (2013). Child Marriage in South Asia: Realities, responses and the way forward. Bangkok: UNFPA Asia Pacific Regional Office.

Lo Bue, M. C., \& Klasen, S. (2013). Identifying synergies and complementarities between MDGs: Results from cluster analysis. Social Indicators Research, 113(2), 647-670.

Mahmud, W., Asadullah, M. N., \& Savoia, A. (2013). Bangladesh's achievements in social development indicators: Explaining the puzzle. Economic and Political Weekly, 48(44), 26-28.

Male, C., \& Wodon, Q. (2017). Child marriage and early childbirth: Trend and profile for 25 countries. In Education global practice. Washington, DC: The World Bank.

Malla, D. S., Giri, K., Karki, C., \& Chaudhary, P. (2011). Achieving millennium development goals 4 and 5 in Nepal. BJOG: An International Journal of Obstetrics and Gynaecology, 118(S2), 60-68.

Osmani, S. R. (2018). Socio-economic development in South Asia: The past 50 years. In WIDER working paper 2018/105.

Page, L., \& Pande, R. (2018). Ending global poverty: why money isn't enough. Journal of Economic Perspectives, 32(4), 173-200.

Pal, S. (2010). Public infrastructure, location of private schools and primary school attainment in an emerging economy. Economics of Education Review, 29, 783-794.

Pritchett, L. (2009) Is India a flailing state?: Detours on the four lane highway to modernization. In HKS Faculty Research Working. Paper Series RWP09-013, John F. Kennedy School of Government, Harvard University.

Pritchett, L. (2014). The rebirth of education: Schooling Ain't learning. Washington: Center for Global Development.

Pritchett, L., \& Sandefur, J. (2017) Girls' schooling and women's literacy: Schooling targets alone won't reach learning goals. In CGD policy paper. Washington, DC: Center for Global Development.

Rama, M., Béteille, T., Li, Y., Mitra, P. K., \& Newman, J. L. (2015) Addressing inequality in South Asia. In South Asia development forum. World Bank Group, Washington, DC.

Ranis, G., \& Stewart, F. (2012). Success and failure in human development, 1970-2007. Journal of Human Development and Capabilities, 13(2), 167-194.

Roy, S., Ara, J., Das, N., \& Quisumbing, A. (2015). Flypaper effects in transfers targeted to women: Evidence from BRAC's "Targeting the Ultra Poor" program in Bangladesh. Journal of Development Economics, 117(C), 1-19.

Sandefur, J., Pritchett, L., Beatty, A. (2016). Learning profiles: The learning crisis is not (Mostly) about enrolment. In Society for research on educational effectiveness conference paper.

Savoia, A., \& Sen, K. (2015). Measurement, evolution, determinants, and consequences of state capacity: a review of recent research. Journal of Economic Surveys, 29(3), 441-458.

Sekher, T. V. (2012). Ladlis and lakshmis: Financial incentive schemes for the girl child. Economic and Political Weekly, XLVII(17), 58-65.

Sen, A. (1999). Development as freedom. Oxford: Oxford University Press.

Sen, B., \& Ali, Z. (2015). Ending extreme poverty in Bangladesh during seventh five year plan: Trend, drivers and policies. In Background paper for the preparation of Seventh Five Year Plan, General Economics Division (GED). Government of Bangladesh.

Smith, S. L., \& Neupane, S. (2011). Factors in health initiative success: Learning from Nepal's newborn survival initiative. Social Science and Medicine, 72(4), 568-575. 
Snilstveit, B., Stevenson, J., Menon, R., Phillips, D., Gallagher, E., Geleen, M., Jobse, H., Schmidt, T., \& Jimenez, E. (2016). The impact of education programmes on learning and school participation in low- and middle-income countries: A systematic review summary report. In 3ie systematic review.

Solotaroff, J. L., Pande, R. P. (2014). Violence against women and girls: Lessons from South Asia. In South Asia Development Forum. Washington, DC: World Bank Group.

The Economist. (2016). Women's education in Afghanistan. 13th April 2016.

UNCTAD. (2016). The least developed countries report 2016.

UNDP. (2010). Power, voices and rights. A turning point for gender equality in Asia and the Pacific. In United Nations Development Programme Technical Report. Macmillian Publishers India Ltd., Sri Lanka.

UNESCAP. (2017). Achieving the sustainable development goals in South Asia: Key policy priorities and implementation challenges. https://www.unescap.org/sites/default/files/publications/Report_ Achieving_the_Sustainable_Development_Goals_in_South_Asia_12052017.pdf.

UNESCO. (2014). United nations educational, scientific and cultural organization's education for all global monitoring report 2014.

UNICEF. (2014). Cost of inaction: Child and adolescent marriage in Nepal. In Nepal working paper series.

United Nations. (2015). The Millennium Development Goals report 2015. New York: United Nations.

United Nations. (2016). The Sustainable Development Goals report 2016. New York: United Nations.

Weststrate, J., Dijkstra, G., Eshuis, J., et al. (2019). The Sustainable Development Goal on water and sanitation: learning from the Millennium Development Goals. Social Indicators Research. https://doi. org/10.1007/s11205-018-1965-5.

World Bank. (2016). Moving up the ladder: Poverty reduction and social mobility in Nepal. Kathmandu: World Bank.

World Bank. (2017). World development indicators 2017. Washington, DC: World Bank.

World Bank. (2018). The World Development Report 2018: Learning to Realize Education's Promise. Washington DC: The World Bank.

Publisher's Note Springer Nature remains neutral with regard to jurisdictional claims in published maps and institutional affiliations. 